\title{
The structural heterogeneity of family farming in Brazil
}

\author{
José Eustáquio Ribeiro Vieira Filho
}

ABSTRACT

Regional and productive inequality may stem from the agricultural modernization process, in which some agents are able to incorporate and absorb technological content, while others are excluded, not only from the innovative organizational environment, but also from learning processes and the dissemination of new production techniques and knowledge. This paper analyses family farming, by making comparisons in regional terms and by groups of producers using high, medium and low technology. It also calculates the productive inequality index (Gini coefficient of gross income) of the north, north-east, centre-west, south-east and south regions. In view of the regional differentiation, the size of enterprises and the various levels of technological growth, public policies should focus on reducing the disparities that hamper the dissemination of new knowledge and productivity growth among economic agents, leading to greater productive inclusion.

JEL CLASSIFICATION

KEYWORDS

AUTHOR
Q16, O3, O4

Agriculture, small farms, family, productivity, measurement, evaluation, agricultural development, Brazil

José Eustáquio Ribeiro Vieira Filho is a research officer at the Institute of Applied Economic Research (IPEA).jose.vieira@ipea.gov.br 


\section{I}

\section{Introduction}

The agricultural modernization process can lead to regional and productive inequality, because some economic agents are able to incorporate and absorb technological content, while others remain excluded from the innovative organizational environment, and from learning processes and the dissemination of new techniques and productive knowledge.

Incorrect public policies distort relative prices and hinder access to technology and credit, thereby discouraging the entry of producers who have fallen behind in the technology race. Because climatic and regional factors cause productive differences in various types of crop, less innovative producers become more vulnerable to exogenous fluctuations in production and to factors that are specific to their location.

As noted by Vieira Filho and Silveira (2011), producers adopt technological inputs for the purpose of increasing productivity and reducing relative production costs. Nonetheless, in some situations farmers have no incentive to adopt new techniques and knowledge, since the higher cost involved in incorporating a new technology is not offset by the expected yield. In most cases, farmers who are lagging behind in technological content are in a poverty situation, so they need other sources of nonfarm income to survive.

Apart from the economic issues involved in deciding what to produce and what resources to use, the producer's investment decision has two basic functions: the first refers to the generation of technological innovation and the second to the expansion of capacity to absorb new knowledge and technologies (Evenson and Kislev, 1973; Cohen and Levinthal, 1989; Vieira Filho and Silveira, 2011). Importantly, the better the organizational environment in which production takes place — which can stimulate the technological diffusion process- the greater the cumulative knowledge among economic agents and the better the absorption of external technology.

The empirical analysis of family farming in Brazil's southern region will verify that point. Traditionally, this is the country's most dynamic region and reports the best

$\square$ The author is grateful for suggestions made by the anonymous referee, and also thanks colleagues who participated in the ECLAC/ IPEA project "Structural heterogeneity in the Brazilian economy" and contributed to the development of this research. Nonetheless, they are not responsible for any errors or omissions contained in this document. economic development indicators — an achievement that both requires and also reflects the adequate institutional and technological base that has been developed over time. The same productive environment that fosters innovation does not exist in the north-east. A better understanding of the structural heterogeneity of family farming is needed, with a view to proposing inclusive production solutions that can benefit the regions that are least advanced in this process.

The limited nature of technical assistance and rural extension services compromises the organizational environment, which in turn impairs the exchange of experiences between economic agents and consequently slows down the technology-transfer process. The more structured the productive chain, the more easily knowledge can be disseminated and absorbed by productive agents. In more developed regions, available resources are used more efficiently, and this generates higher land or labour productivity thanks to lower production costs.

Some agricultural crops are integrated into modern value chains that encompass the private sector and public research organizations (universities and rural extension services). Others, though, are excluded from investments in research and development (R\&D), so their participation in production lines is limited and they have little incentive for technological development.

According to ECLAC (2010), the discussion of structural heterogeneity reveals development disparities in Latin America with respect to the central countries, especially in terms of regional, sectoral and intrasectoral labour productivity. In the case of agriculture, Pinto (1970) estimates that labour productivity in crop farming included in the "modern" sector is about 14 times higher than that prevailing in the "primitive" sector, noting also that both modern and outdated production arrangements coexist.

Following the methodology presented by Vieira Filho, Santos and Fornazier (2012), this study analyzes the structural heterogeneity of family farming in Brazil, classifying farms in technology groups and according to productive concentration. ${ }^{1}$ The aim is to investigate whether the process of technological innovation in

1 This study complements the analyses made in Buainain (2007) by updating the data on family farming reported by the 2006 agricultural census, which was published in only 2009. 
family farming, in conjunction with regional specifics, contributes to greater productive inequality, which, when it is structural, makes it unviable to include farmers that are on the margins of the technological dynamic. According to the basic hypothesis, technological innovations driven by institutional changes, in conjunction with regional and productive specifics, contribute to greater inequality in agricultural production and growth, favouring dynamic

\section{II}

\section{Methodology}

\section{Family farming}

The aim of this study is to investigate the smallest familyrun farms or enterprises, which account for the vast majority of rural producers (84\% of all establishments). This group is also considered the most vulnerable in terms of access to technology, although this is not always true, as will be seen in the analyses. While the term "family farming" is not entirely appropriate, the analysis was restricted to this group because there is a legal criterion for the distinction which defines public policies to promote the sector.

Pursuant to the legal guidelines for agriculture policy-making in Brazil (Brasil, 2006), a rural family entrepreneur is defined as someone who engages in activities in the rural area and also satisfies the following requirements: (i) does not legally own a land area larger than four fiscal modules; (ii) predominantly uses family labour in the economic activities of the establishment; (iii) has a family income that originates mainly in economic activities linked to the establishment or enterprise, and (iv) operates the establishment or enterprise with his/ her family.

Size, measured in terms of fiscal modules, is obtained by dividing the total area of the rural property by the fiscal module for each municipality, which is defined in hectares (ha) and takes the following into account: (i) the type of farm operation prevalent in the municipality; (ii) income earned from the operation in question; and (iii) the other operations in the municipality which, though not predominant, are considered on the basis of income or the area used and the concept of family property. It is calculated to determine the size of rural properties and classify them as smallholdings, or as small, medium, and large properties for public-policy purposes. In some and innovative organizational zones, while regions that are excluded from modern production stagnate.

This article is divided into three sections, following this brief introduction. Section II discusses the analytical method, defining the subdivision of technological groups and presenting the calculation of the productive inequality index (PII). Section III discusses the empirical results; and section IV sets forth the final considerations. cases there are farmers who own more than 100 hectares of land, which, for international comparison purposes, are classified as large rural producers. In other cases, as there is enormous heterogeneity, technology access is highly differentiated. Accordingly, the standardization of public policies could create distortions in the allocation of scarce and limited resources.

The methodology adopted in this paper seeks to classify family farms in groups according to their technological efficiency and the organization of the institutional environment in which production takes place; and to verify how productive concentration occurs in the farms in that classification. There is no doubt that massive dissemination of technology can help eliminate rural poverty, increase productivity and deconcentrate income. For that purpose, the study uses data from the 2006 Agricultural Census conducted by the Brazilian Institute of Geography and Statistics (IBGE).

\section{Methodological taxonomy}

To gain a better understanding of the structural heterogeneity of production in Brazilian agriculture, Vieira Filho and Santos (2011) constructed a taxonomy of high, medium and low technological and institutional efficiency, based on both economic and qualitative criteria. The economic criteria are linked to total factor productivity (TFP), while the qualitative refer to the level of technology and institutional organization of the economic agents (high and low technological and institutional content: HT and LT, respectively).

Under the economic criterion, TFP was calculated because it can be interpreted as the value of gross income generated by each monetary unit of cost (Alves Souza and Oliveira, 2006). Both the production function 
chosen and the input mix affect this measure. Total factor productivity can be measured by dividing gross income by total production cost; and net income is gross income minus total cost. Thus, a TFP of less than 1 means that gross income is less than total cost, which therefore represents a negative net income. The reverse is also true: when the TFP is greater than 1 , net income is positive.

The analysis of TFP cannot be decoupled from a temporal analysis, since annual fluctuations in production can be caused by exogenous shocks such as climate changes, crop failures, the emergence of new pests or changes in international price levels. As the analysis only covered the year 2006, however, qualitative criteria were added to the study.

For this purpose, Vieira Filho and Santos (2011) formulated 22 yes/no questions on the use of different technologies and the agents' degree of institutional organization, such as whether the establishment makes use of fertilizers, products to chemically correct the soil, pesticides, tractors, technical assistance, financing, cooperativism, the National Register of Legal Entities, pest control and storage units, among others. To divide the properties into high and low technological and institutional content, the proportion of establishments was graphed according to the frequency with which they responded "yes" to the questions posed - for example, establishments that responded in the affirmative once; those responded "yes" twice, and so on up to the 22nd question. Values that exceed the average of the distribution were classified as HT and values below average as LT.

By blending the economic and qualitative criteria, a taxonomy was defined for the technological efficiency of productive establishments. Table 1 shows the resulting technological-efficiency groupings. It is worth noting that the taxonomy serves only to schematize the groups of establishments, and several derived variables will need to be calculated to compare the different groups. Data are available to quantify gross income, total cost, investment (capital, labour and technologies), the value of capital, net income and labour productivity.

To gain a better understanding of the importance of technology in agriculture, Vieira Filho, Campos and Ferreira (2005) use a Leontief production function with fixed proportions of two types of capital. The output of agricultural activity in period $i$ is equal to the minimum ratio between capital employed (fixed capital $K f_{i t}$; or variable capital $\left.K v_{i t}\right)$ and their technical coefficients $\alpha$ and $\beta$. Then: $K f_{i t}=\alpha \cdot Q_{i t}$ and $K v_{i t}=\beta \cdot Q_{i t}$. So production $Q_{i t}$ is limited to the maximum given by the minimum combination of those two factors. If $K f_{i t} / \alpha<K v_{i t} / \beta$, there will be a surplus of the second factor. If the opposite occurs, $K f_{i t} / \alpha>K v_{i t} / \beta$, there will be surplus of fixed capital. Thus, the production function is defined as follows:

$$
Q_{i t}=\min \left\{\frac{K f_{i t}}{\alpha} ; \frac{K v_{i t}}{\beta}\right\}
$$

The relations between fixed capital and variable capital is given by a constant, with $K v_{i t} / K f_{i t}=z_{i t}$. Moreover $\left(K v_{i t} / \beta\right) /\left(K f_{i t} / \alpha\right)=n$; so $\left(K v_{i t} / \beta\right) .\left(\alpha / K f_{i t}\right)=n$. Thus, making the substitution, the result is $n \cdot(\beta / \alpha)=z_{i t}$. The parameters $(\alpha$ and $\beta)$ are determined at the outset, with $n$ a constant defining proportionality between the different types of capital. In the initial state of the system, $z_{i t}$ is given. Thus $\alpha=1 / A f_{i t}$ and $\beta=1 / A v_{i t}$, where $A f_{i t}$ is the productivity of fixed capital (represented by labour-saving technologies), and $A v_{i t}$ is the productivity of variable capital (represented by land -saving technologies).

Agricultural growth depends on capital growth. To reconcile the combination of land-saving and laboursaving technologies, fixed capital growth is restricted to the growth of variable capital, and vice versa. To quantify the land-saving technologies (linked to variable capital), a proxy variable was formed from the sum of expenditures on seeds and seedlings, products to correct soil chemistry, fertilizers, agrochemicals, animal feed and

TABLE 1

Taxonomy by technological-efficiency group

\begin{tabular}{lcccc}
\hline Economic criterion - economic efficiency & \multicolumn{2}{c}{ TFP $>1$} & TFP $<1$ \\
\hline Qualitative criterion - technological/institutional content & HT & LT & HT & LT \\
Technological groups & 1st group & 2nd group & 3rd group & 4th group \\
Taxonomy - technological efficiency & High & & Medium & Low \\
\hline
\end{tabular}

Source: prepared by the author.

TFP: total factor productivity.

HT: high technological and institutional content.

LT: low technological and institutional content. 
veterinary medicines. Labour-saving technologies (related to fixed capital) were represented by an estimate of the value of vehicles, tractors, machinery and implements (with a depreciation of $6 \%$ and an average lifespan of 15 years), plus machinery rental. This makes clear the importance of quantifying technologies in agricultural activities where different productive inputs are combined.

\section{Productive inequality index (PII)}

Labour productivity, measured by dividing value added by persons employed in each productive establishment, is the reference variable that quantifies structural heterogeneity in ECLAC studies. ${ }^{2}$ The greater the dispersion of labour productivity, the greater the diversity of production and probably also the greater the structural inequalities. In order to visualize the system's productive inequalities, the minimum wage equivalent (MWE) was specified as gross production value (GPV) per month, divided by the monthly minimum wage. Thus, an attempt was made to stratify gross income (value of production, including consumption) in four income brackets defined by MWE: (1) $0<$ MWE $<=2$ times the minimum wage or "extreme poverty";

2 For comparison, see Pinto (1970); Nohlen and Sturm (1982); Sunkel and Infante (2009), and ECLAC (2010). Moreover, with the publication of the study by the Institute of Applied Economic Research (IPEA, 2011) a technical cooperation agreement was established between IPEA and ECLAC, in the framework of the inclusive development project. A line of research was created in IPEA to study the structural heterogeneity of the Brazilian economy. Thus, attempts were made to expand and enhance the debate and discussion on policies, tools, and strategies for inclusive development in Brazil, in particular analysing labour productivity in the various sectors of economic activity.
(2) $2<$ MWE $<=10$ minimum monthly wages or "low income";

(3) $10<$ MWE $<=200$ minimum monthly wages or "middle income", and

(4) MWE > 200 times the minimum wage or "high income".

Steps were then taken to calculate the Gini coefficient $^{3}$ of gross income for each group in the farm taxonomy based on technological efficiency, and to compare Brazil's different agricultural regions. As productive inequality is calculated between farms, it was decided to call this the Gini productive inequality index (PII), as noted by Vieira Filho, Santos and Fornazier (2012). Moreover, the PII was calculated for a discrete data sample.

Lastly, a comparison is made between the PII and labour productivity measured as the value added per person employed (VA/PE), both being indicators standardized (by subtracting the mean and dividing by the standard deviation). In this comparison four categories are identified, as shown in the quadrants of figure 1:

(1) High productivity with low inequality (best-case scenario, or homogenization of wealth);

(2) Low inequality and low productivity (worst-case scenario, or socialization of poverty);

(3) High inequality and low productivity (heterogeneity in poverty), and

(4) High inequality and high productivity (heterogeneity in wealth).

3 Hoffmann (1998) contains a methodological explanation of inequality measures and the calculation of the Gini coefficient for a discrete data sample.

FIGURE 1

Productive inequality compared to labour productivity

\begin{tabular}{|c|c|}
\hline \multicolumn{2}{|c|}{ (3) } \\
$\begin{array}{c}\text { High inequality and } \\
\text { low productivity }\end{array}$ & $\begin{array}{c}\text { (4) } \\
\text { High inequality and } \\
\text { high productivity } \\
(2)\end{array}$ \\
\hline $\begin{array}{c}\text { Low inequality and } \\
\text { low productivity }\end{array}$ & $\begin{array}{c}\text { VA/PE } \\
\text { Low inequality and } \\
\text { high productivity }\end{array}$ \\
\hline
\end{tabular}

Source: prepared by the author.

PII: productive inequality index.

VA/PE: value added per population employed. 


\section{III}

\section{Analysis of results}

This section will discuss the findings in relation to the structure of family farming. The various studies undertaken previously by Vieira Filho and Santos (2011); Fornazier and Vieira Filho (2012), Vieira Filho, Santos and Fornazier (2012), and IPEA (2011) show that the technological taxonomy, as described in the methodology, displays a high degree of heterogeneity in both family farming and non-family (commercial) farming. As there are groups of high technological efficiency in both types of farming, the subdivision defined by Law No. 11.326 (Brasil, 2006), which sets guidelines for formulating national policy on family farming, is inappropriate for separating groups of producers that require differentiated public policies. If the level of heterogeneity in the family farming is very high, standardized policies cannot be adopted for different levels ${ }^{4}$ each group of producers with similar production systems needs to make specific demands. The aim of the empirical analysis is to test and evaluate the structural heterogeneity that exists in family farming, in terms of income inequality and technological patterns.

Even when the Brazilian agricultural sector is considered more generally, one can clearly discern the existence of several structural flaws that promote sectoral and regional heterogeneity. According to the 2009 National Household Survey, the agriculture sector employed $11 \%$ of the 82.6 million employed persons in Brazil who declared a positive income. Nonetheless, according to Hoffmann (2011), when unpaid workers are included, which is a typical situation among small-scale farmers, its share of all employed persons rises to $17 \%$.

Table 2 presents data from the National Household Survey on the employed population by sector and region, ${ }^{5}$

\footnotetext{
4 Instead of facilitating it, the homogenization underlying the expression "family farming" seriously restricts government action by hindering the formulation of policies to promote small-scale market production. See Navarro and Pedroso (2011) for a critical and sociological evaluation of the concept of family farming in Brazil.

5 It should be noted that the area of agricultural enterprise in the National Household Survey is defined differently from the area of agricultural establishment used in the agricultural census. As this is a household survey, the area in question could be formed by discontinuous land plots, possibly located in different regions. It is also hard for research to capture rural properties owned by legal entities. Accordingly, given the methodological differences, any direct comparison between the National household survey and the agricultural census needs to be interpreted with care.
}

and shows that the agriculture sector in general tends to employ older people with a lower education level than is the case in industry and services. Also, agricultural income is more unequally distributed than in industry, according to the Gini coefficient, although similarly to the service sector. Average income in the agricultural sector is equivalent to $53 \%$ of the level in the services sector. In regional terms, the average income in the centre-west region is more than three times that recorded in the north-east - a region that encompasses nearly half $(43.2 \%)$ of the population employed in agriculture sector with the lowest level of schooling (almost half of this in São Paulo). The average age of agricultural workers is higher than in the industrial and service sectors in all regions of the country, although the average age is highest in the south. In terms of income distribution, the centre-west and south regions are more unequal than in the north, north-east and southeast, São Paulo being the state with the lowest rate of income inequality.

Figure 2 makes a broad comparison between family farming and commercial agriculture, through production-related indicators. The figures show that $84 \%$ of establishments are classified as family farms, and these generate just $34 \%$ of gross income. This disparity could be explained by the low level of spending on technological resources and essentially because GPV is concentrated in a small number of properties and crops (such as soybeans, maize, sugarcane and cotton). ${ }^{6}$ Farms engaging in commercial agriculture account for $16 \%$ of the population, and are those that invest most in capital, labour and technology (both land- and laboursaving). Commercial agriculture generates $66 \%$ of gross income and uses $76 \%$ of available land. In terms of labour productivity, $74 \%$ of the population engaged in agriculture work on family farms, which produce only $34 \%$ of gross income. Although family farms are labour-intensive, a more in-depth empirical analysis reveals low labour productivity, which is related to the problem of structural heterogeneity, albeit differentiated between regions.

\footnotetext{
6 Production is highly concentrated in Brazil, especially in the case of specific crops. Alves and Rocha (2010) provide an idea of that concentration in the cases of milk and cereal production.
} 
TABLE 2

Brazil: income distribution, ${ }^{a}$ schooling and age of persons employed, by economic activity sectors and region, 2009

\begin{tabular}{|c|c|c|c|c|c|c|c|}
\hline \multicolumn{2}{|c|}{ Selected variables } & $\begin{array}{l}\text { Population } \\
\text { (percentage) }\end{array}$ & $\begin{array}{l}\text { Average income } \\
\text { (reais) }\end{array}$ & $\begin{array}{l}\text { Median income } \\
\text { (reais) }\end{array}$ & $\begin{array}{c}\text { Gini } \\
\text { coefficient }\end{array}$ & $\begin{array}{l}\text { Average } \\
\text { schooling }\end{array}$ & Average age \\
\hline \multirow{4}{*}{ Sectors } & Agriculture & 11.0 & 637.4 & 450.0 & 0.529 & 4.0 & 41.7 \\
\hline & Industry & 23.9 & 1041.1 & 700.0 & 0.454 & 8.0 & 36.8 \\
\hline & Services & 64.9 & 1211.6 & 690.0 & 0.526 & 9.7 & 36.8 \\
\hline & Total & 100.0 & 1105.7 & 630.0 & 0.518 & 8.6 & 37.3 \\
\hline \multirow{7}{*}{ Regions } & North & 8.7 & 636.5 & 450 & 0.479 & 3.5 & 40.6 \\
\hline & North-east & 43.2 & 344.1 & 248 & 0.470 & 3.0 & 41.0 \\
\hline & $\mathrm{MG}+\mathrm{ES}+\mathrm{RJ}$ & 16.5 & 664.1 & 465 & 0.444 & 4.4 & 42.3 \\
\hline & São Paulo & 8.8 & 886.5 & 600 & 0.423 & 5.9 & 40.8 \\
\hline & South & 14.9 & 1048.4 & 600 & 0.515 & 5.2 & 43.9 \\
\hline & Centre-west & 7.9 & 1137.5 & 635 & 0.537 & 5.1 & 42.2 \\
\hline & Brazil & 100.0 & 637.4 & 450 & 0.529 & 4.0 & 41.7 \\
\hline
\end{tabular}

Source: 2009 National Household Survey on the basis of R. Hoffmann, "Distribuição da renda agrícola e sua contribuição para a desigualdade de renda no Brasil”, Revista de Política Agrícola, year XX, No. 2, Brasilia, Secretariat of Agricultural Policy, 2011 , pages 9 and 10.

a Positive labour income.

MG: Minas Gerais. es: Espírito Santo. RJ: Rio de Janeiro.

FIGURE 2

Brazil: share of commercial and family farming by selected indicators, 2006

(Percentages)

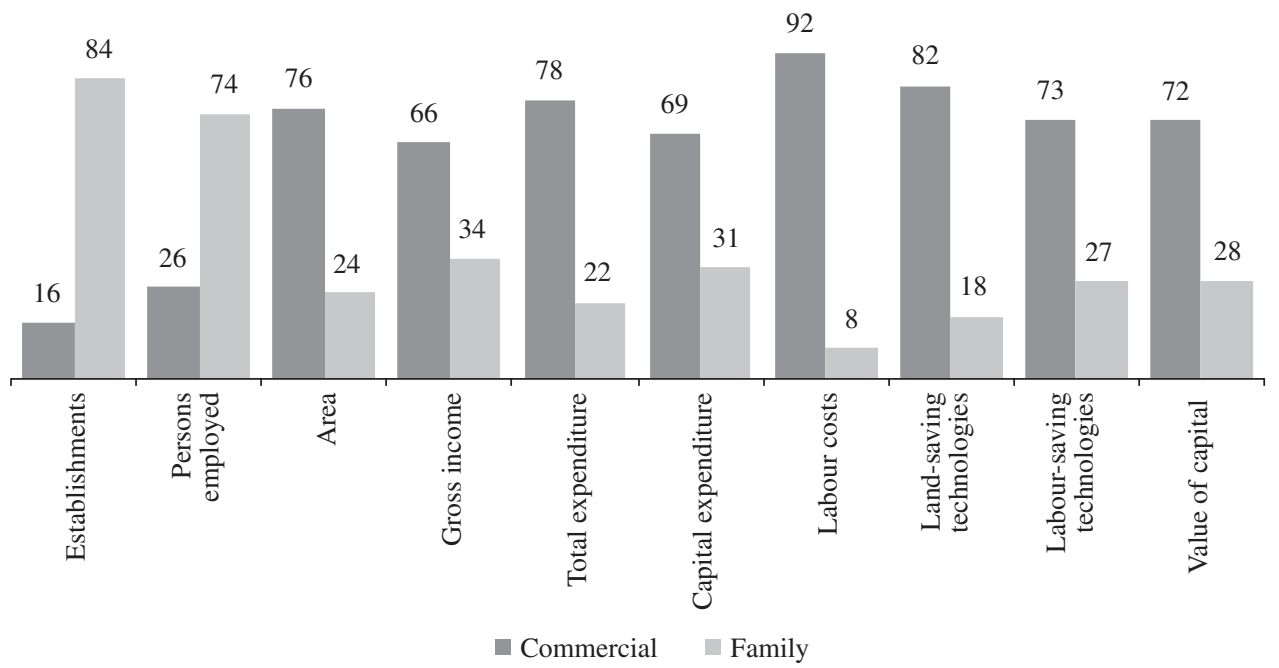

Source: prepared by the author on the basis of Brazilian Geographical and Statistical Institute (IBGE), 2006 Census of Agriculture.

Table 3 classifies family farming establishments in four income levels: extreme poverty, and low, middle and high income. At the upper end of the population distribution, represented by middle- and high-income groups, the figures show that $5.2 \%$ of farms generated
$63.5 \%$ of GPV. At the lower end, consisting only of the extreme poverty group, $66.4 \%$ of farms contributed around $10 \%$ of GPV. Thus, there is a strong pattern of income concentration and a heavy weight of extreme poverty in family farming; and a small number of 
Brazil: stratification of income from family farming by number of establishments and production, 2006

\begin{tabular}{|c|c|c|c|c|c|c|c|}
\hline $\begin{array}{l}\text { Income groups by } \\
\text { minimum wage } \\
\text { equivalent }\end{array}$ & $\begin{array}{l}\text { Minimum wage } \\
\text { equivalent } \\
\text { (MWE) }^{\mathrm{a}}\end{array}$ & $\begin{array}{l}\text { Share of family } \\
\text { farms } \\
\text { (percentages) }\end{array}$ & $\begin{array}{l}\text { Share of family } \\
\text { farm production } \\
\text { (percentages) }\end{array}$ & $\begin{array}{l}\text { Number of family } \\
\text { farms }\end{array}$ & Percentage & $\begin{array}{l}\text { Annual GPV of } \\
\text { family farming } \\
\text { (billions of reais) }\end{array}$ & Percentage \\
\hline & Not reported & 86.3 & $\ldots$ & 461000 & 10.6 & $\ldots$ & $\cdots$ \\
\hline Extreme poverty & (0 to 2$]$ & 89.5 & 87.3 & 2.9 million & 66.4 & 5.7 & 10.2 \\
\hline Low income & (2 to 10$]$ & 81.0 & 79.4 & 778000 & 17.8 & 14.7 & 26.2 \\
\hline Middle income & (10 to 200$]$ & 53.8 & 41.3 & 224000 & 5.1 & 24.7 & 44.1 \\
\hline High income & $>200$ & 15.7 & 13.3 & 4000 & 0.1 & 10.9 & 19.4 \\
\hline Total - Brazil & & 84.4 & 33.6 & 4.4 million & 100.0 & 56.1 & 100.0 \\
\hline
\end{tabular}

Source: prepared by the author on the basis of Brazilian Geographical and Statistical Institute (IBGE), 2006 Census of Agriculture.

${ }^{\text {a }}$ Minimum wage equivalent $=$ gross production value $(\mathrm{GPV})$ per month/ monthly minimum wage.

establishments (which encompass the wealth of family farming) produce more than half of GPV.

The extreme poverty group, consisting of about 2.9 million establishments, is on the fringes of agricultural production and excluded from any economic sector, since it lacks efficient productive organizational structures (microeconomic and market). In the economy as a whole, family farms account for $89.5 \%$ of extreme poverty, with the north-east region in particular accounting for $61 \%^{7}$ of the extremely poor in Brazilian family farming. As previously noted by Vieira Filho, Santos and Fornazier (2012), resolving this distortion is extremely complex and requires comprehensive structural policies, such as an in-depth reform of education, improvements in the health sector, and the provision of basic market infrastructure. Alves and Rocha (2010) claim that population groups that work on the land are more likely to migrate to urban centres. Thus, notwithstanding the formulation of longterm structural policies, short-term measures are also required, including policies to support disadvantaged groups and income transfer.

The government should assist the low-income group through development policies and measures to reinvigorate small-scale production, which is normally family-based. The producers in question operate with low levels of technology and have little capacity to absorb external knowledge, compounded by shortcomings in the management and microeconomic areas. Access to credit needs to be improved and the use of new technologies

7 This share is calculated by dividing the total number of establishments in the (0-2) income bracket in Brazil as a whole (2 900.1) by the total number of establishments in the same income bracket in the north-east region (1 767.9). encouraged. It is the government's responsibility to create technical assistance that reaches the grassroots level, and to undertake research in the public domain when the market fails to provide this. In family farming, this group consists of 778,000 farms, most of which are located in the southern region (about 41\%), ${ }^{8}$ which contains almost twice the number of family farms generating low incomes, compared with the south-east and north-east which have $21 \%$ of such establishments each.

Lastly, the country's agricultural wealth also includes middle- and high-income groups. The south has the largest absolute number of medium- and high-income family farms, consisting of around 100,000 establishments, or $44 \%$ of the national total. In contrast, the centrewest region has the fewest $(11,600)$, representing 5\% of establishments in the family farming universe. For this group, while technology absorption capacity is a secondary problem, a macroeconomic environment conducive to sales growth is essential. Public policies should be designed on the basis of issues that extrapolate productive microeconomic side, with a focus on stimulating market competitiveness, export promotion and agricultural insurance, while also improving the logistical distribution of products and thus reduce costs.

In a general analysis of the economic viability of family farms, figure 3 displays the TFP economic criterion. According to Gasques and others (2010), from 1970 to 2006 most agricultural output growth was driven by TFP growth. While agricultural production grew by $243 \%$

8 Analogously to note 7 , the percentage is calculated by dividing the total number of establishments in income bracket (2-10] in Brazil as a whole (777.5) by the total number of establishments of the equivalent income bracket in the southern region (317.1). 
between 1970 and 2006, input use expanded by just $53 \%$ in that period. This proves that the overall growth of Brazilian agriculture was based primarily on productivity increases or technological upgrading. Of the 4.4 million family farms in the Brazilian agriculture sector in 2006, about $42 \%$ had a gross income exceeding total costs, which represented a TFP greater than 1 . Interestingly, the majority of establishments $(58 \%)$ faced financial difficulties and had a TFP below 1 , or negative net income.

FIGURE 3

\section{Brazil: classification of family farms under the TFP economic criterion, 2006 (Millions and percentages)}

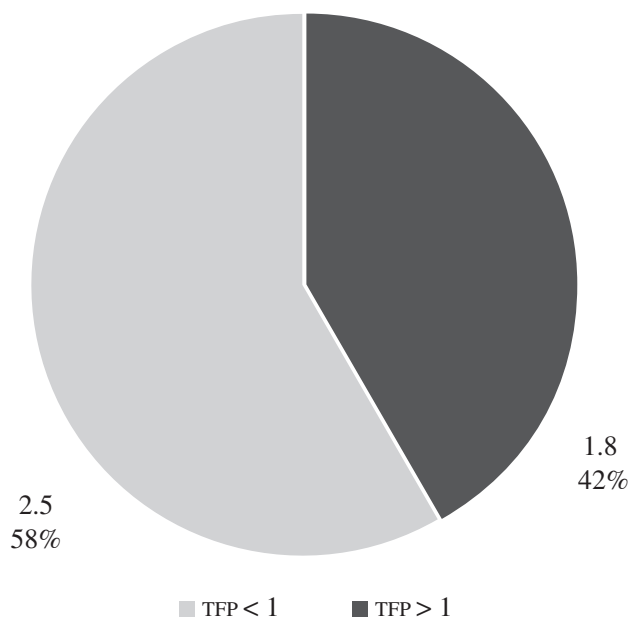

Source: prepared by the author on the basis of Brazilian Geographical and Statistical Institute (IBGE), 2006 Census of Agriculture.

TFP: total factor productivity.

Understanding the economic viability of family farms in the Brazilian economy required an analysis of the producers' technological efficiency rating. The joint classification of the economic and qualitative criteria is shown in table 4 , which summarizes the family-farm sector classified in technology groups and by selected economic indicators. In the case of gross income, family farmers on average earned less than half the national average income for the entire agricultural sector, including commercial agriculture. In the case of family farming, establishments with a TFP greater than 1 and high technological content have a gross income that exceeds the Brazilian average. Nonetheless, there are also highly productive establishments in family farming; and this simple finding is important because it shows public-sector managers that productive development policies need to be contextually differentiated, and merely distinguishing between family and commercial farming to separate groups of farmers with similar demands is insufficient.

In terms of the average area per farm, those with negative net income had areas that were larger than average for family farming, which shows that it is not always the owner with the largest area that earns highest gross income. When studying technology in agriculture, land is a factor used in the production process. While land is clearly highly relevant to this process, higher technology can generate savings on land use and increase production. If technology has this capacity, the land (since it is a given) becomes secondary resource. While bringing more land into use may increase final output, productivity grows only by incorporating more technology. The fact that agents with a high technological intensity have a smaller average farm area than their low-intensity counterparts, shows that technology is more important than land area for obtaining a higher income (or to combine the efficient use of resources to increase production). ${ }^{9}$

In terms of technologies (whether land - or labour-saving), family firms of high technological content have costs that are lower than the country average; nonetheless, their expenses are higher than the average for family farming. As those establishments use technological inputs above the average level, expenditure on technologies exceeds the average results reported for family farming generally. If future increases in production fail to compensate for the increase in investment in technological inputs, production costs rise and the establishments face financial difficulties, as is the case of the group defined by medium technological efficiency and negative net income, in other words $20 \%$ of all establishments. At the other extreme - low cost and high productivity - establishments benefit from a positive net income, a situation pertaining to $19 \%$ of total establishments, represented by low technological content and a TFP above 1.

In general, family farms invest less in technology than other sectors of the economy and so generate less

9 Analysing wealth creation by only considering the land endowment is a mistake. Those who claim that family farming is needed more than employe-based farming, analyse the problem by focusing only on the issue of land. According to Brasil (2006) in the classification of family farming compared to employment based (or non-family) farming, the land factor was considered as a criterion of exclusion. The division takes account of the size of the land area and not economic criteria (sales value, TFP and net income, among others). The results reported here testify to the high level of productive heterogeneity in Brazilian agriculture. Tehchnology is a key issue for discussing this problem. 
TABLE 4

Brazil: comparison of family farming by technological-intensity group and selected economic indicators, 2006

\begin{tabular}{|c|c|c|c|c|c|c|c|c|}
\hline \multirow{3}{*}{\multicolumn{3}{|c|}{ Economic and qualitative criteria }} & \multicolumn{4}{|c|}{ Family } & \multirow{4}{*}{$\begin{array}{l}\text { Total } \\
\text { family }\end{array}$} & \multirow{4}{*}{ Brazil } \\
\hline & & & \multicolumn{2}{|c|}{$\mathrm{TFP}>1$} & \multicolumn{2}{|c|}{$\mathrm{TFP}<1$} & & \\
\hline & & & HT & LT & HT & LT & & \\
\hline \multicolumn{3}{|c|}{ Taxonomy - technological intensity } & High & \multicolumn{2}{|c|}{ Medium } & Low & & \\
\hline \multirow{10}{*}{ 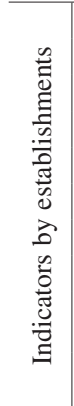 } & \multirow{8}{*}{ 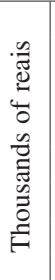 } & Gross income (GI) & 39.7 & 13.6 & 6.6 & 1.7 & 12.8 & 32.2 \\
\hline & & Total cost (TC) & 11.8 & 2.5 & 14.9 & 5.7 & 8.3 & 32.5 \\
\hline & & Capital expenditure (CE) & 1.0 & 0.1 & 1.2 & 0.2 & 0.6 & 1.6 \\
\hline & & Labour cost (LC) & 0.6 & 0.1 & 0.9 & 0.3 & 0.5 & 4.5 \\
\hline & & Expenditure on land saving technologies & 3.8 & 0.3 & 4.3 & 0.5 & 2.0 & 9.5 \\
\hline & & Expenditure on labour-saving technologies & 0.6 & 0.0 & 0.8 & 0.1 & 0.4 & 1.1 \\
\hline & & Value of capital (VC) & 99.0 & 24.0 & 132.9 & 65.8 & 78.3 & 239.7 \\
\hline & & Net income (NI) & 27.9 & 11.1 & -8.3 & -4.0 & 4.5 & -0.3 \\
\hline & ż & Population employed (PE) & 3.2 & 2.9 & 2.9 & 2.5 & 2.8 & 3.2 \\
\hline & $\Xi$ & Area (hectares) & 15.5 & 12.6 & 19.1 & 23.1 & 18.3 & 64.5 \\
\hline \multirow{8}{*}{ 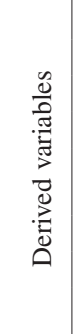 } & \multicolumn{2}{|c|}{ TFP } & 3.4 & 5.5 & 0.4 & 0.3 & 1.5 & 1.0 \\
\hline & \multicolumn{2}{|r|}{ Productivity of land (gross income per ha) (reais) } & 2571.7 & 1077 & 343.1 & 73.4 & 699.8 & 499.4 \\
\hline & \multicolumn{2}{|r|}{ Productivity of capital (GI/CE) } & 39.5 & 130.2 & 5.4 & 6.9 & 21.9 & 20.4 \\
\hline & \multicolumn{2}{|c|}{ Productivity of labour (GI/LC) } & 63.9 & 107.4 & 7.6 & 5.6 & 28.1 & 7.1 \\
\hline & \multicolumn{2}{|r|}{$\begin{array}{l}\text { Share of land-saving and labour-saving technologies } \\
\text { in total cost (percentages) }\end{array}$} & 37 & 14 & 34 & 11 & 28 & 33 \\
\hline & \multicolumn{2}{|c|}{ Capital-labour ratio } & 1.6 & 0.8 & 1.4 & 0.8 & 1.3 & 0.3 \\
\hline & \multicolumn{2}{|c|}{ Rate of return on capital ( $\mathrm{NO} / \mathrm{vC})$} & 0.3 & 0.5 & -0.1 & -0.1 & 0.1 & 0.0 \\
\hline & \multicolumn{2}{|r|}{ Productivity of labour (VA/PE) (thousands of reais) } & 8.9 & 3.9 & -2.3 & -1.0 & 2.0 & 2.1 \\
\hline \multicolumn{3}{|c|}{ Establishments (thousands) } & 837 & 993 & 1022 & 1515 & 4366 & 5176 \\
\hline \multicolumn{3}{|c|}{ Share of establishments (percentages) } & 16 & 19 & 20 & 29 & 84 & 100 \\
\hline
\end{tabular}

Source: prepared by the author on the basis of Brazilian Geographical and Statistical Institute (IBGE), 2006 Census of Agriculture.

Note: monetary amounts expressed in reais at 2006 prices.

TFP: total factor productivity.

HT: high technological/institutional content.

LT: low technological/institutional content.

VA/PE: value added per population employed.

GI/GC: gross income/capital expenditure.

NI/VP: net income/value of capital.

value added per worker. Firstly, labour productivity in family farming is 2,000 reais per person, compared to an estimated 2,100 reais for the Brazilian agriculture sector as a whole. Nonetheless, family farming with positive net income is extremely efficient from the TFP standpoint, and represents $35 \%$ of total establishments. Family farms that are profitable and have low technological content have the highest TFP, owing to the relatively high productivity of the land compared to establishments that have low technology costs. Family production reporting positive net income obtained productivity indices above the national average.
With regard to the taxonomy, the low technologicalefficiency group consists of unproductive establishments. The weak performance of this group is partly due to greater use of land, usually associated with a smaller share in gross income. Public actions should firstly focus on technology promotion policies, which encourage the efficient use of resources. Then, through a carrot-andstick mechanism, the government would create policies setting higher regional productivity targets, in order to monitor the opportunistic behaviour of producers of weak productivity performance, prioritizing agents with the greatest potential for dynamic market integration and 
greater fulfilment of the productivity growth targets. Lastly, it is worth noting that lack of dynamism is linked to poor technological absorption capacity and also, to some extent, to rural poverty. This group should be assisted mainly through structural policies (improvements in education, health and infrastructure, combined with actions for disadvantaged groups and income transfer), although the solution to the problem would hardly be immediate.

Figure 4 compares labour productivity in the agriculture sector with that in other sectors of the economy using IBGE national accounts data for value added per person employed between 2000 and 2007. By stratifying technology groups in agriculture, only in the case of establishments with positive net income (commercial and family) was it possible to compare heterogeneity in the Brazilian agricultural sector, although only for 2006 (the Agriculture Census reference year).

Global data show that Brazilian agriculture is less productive than the industry and service sectors.
However, technological stratification reveals a high degree of variability in labour productivity across productive establishments. This variability may be due to the specific nature of the technological path followed by agriculture. Productive agents have different abilities to absorb technological knowledge. The most productive farmers have a labour productivity nearly seven times the national average, in some cases surpassing the industrial and service sectors. Nonetheless, labour productivity in family farming varies much less than in the commercial agriculture, although this does not mean that structural heterogeneity is less in family farming. In particular, family farming is homogeneous in terms of the "socialization of poverty," which needs to be studied to more effectively plan the development of that type of productive organization.

According to Matteo (2011), labour productivity varies considerably across sectors and regions. In sector terms, labour productivity in industry was around 1.2 times that of services, but close to 4.5 times

FIGURE 4

Brazil: labour productivity by economic activity sector, 2000-2007 (Thousands of reais)

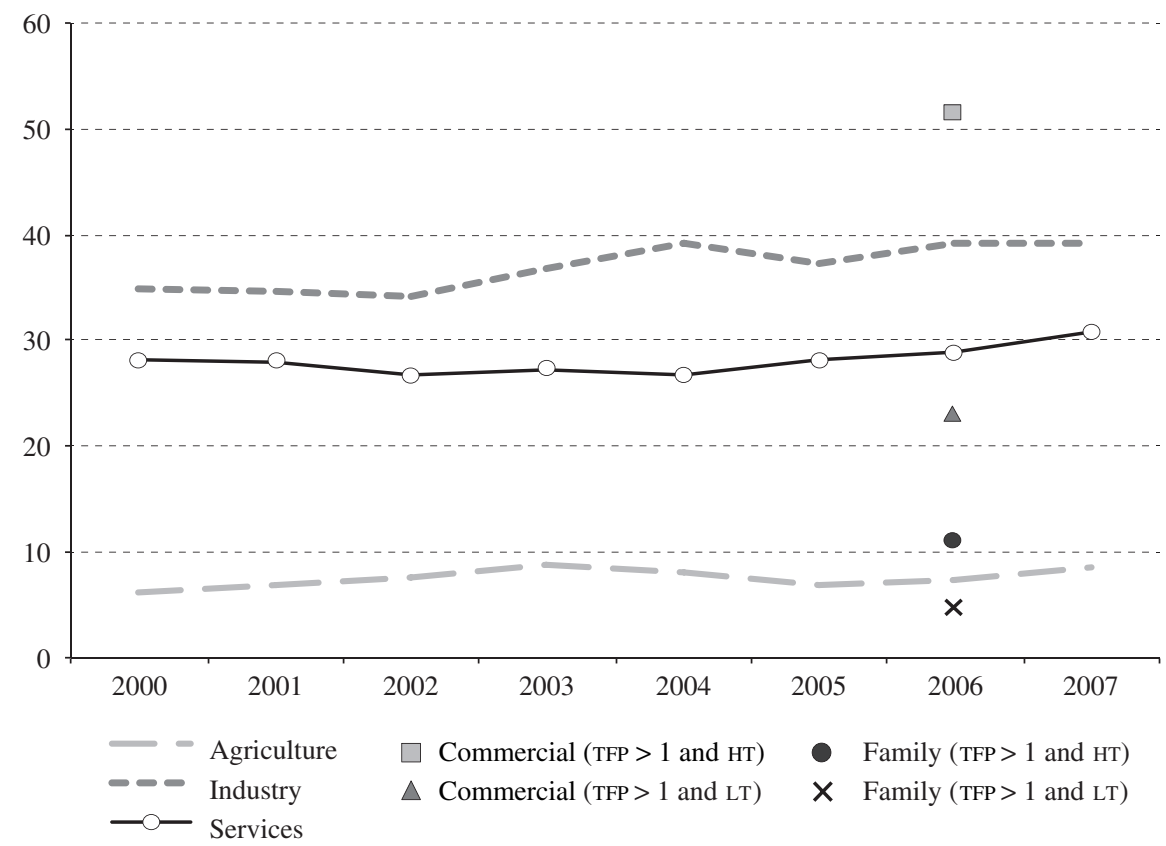

Source: prepared by the author on the basis of Brazilian Geographical and Statistical Institute (IBGE), 2006 Census of Agriculture.

Note: amounts corrected on the basis of the Extended National Consumer Price Index (IPCA), at December 2010 prices.

TFP: total factor productivity.

HT: high technological/institutional content.

LT: low technological/institutional content. 
labour productivity in the agriculture sector as a whole (family and commercial), indicating greater productive heterogeneity in the latter comparison. In regional terms, the industry/agriculture labour productivity ratio was 6.5 in the north-east and 1.2 in the centre-west region. According to the author, the highly productive centrewest farming region (extensive soybean and livestock breeding), where few workers are employed, stands in stark contrast to farming in the north-east, which is what is often at subsistence level.

Table 5 makes a regional comparison of family farming by technological-intensity group. The PII is calculated to verify regional patterns of production; and it is interesting to note that there are different patterns of behavior. In the north-east, family farming is more varied and accounts for much of the poverty in the region, although both modern and backward sectors coexist. In contrast, in the south, the production pattern is more uniform and concentrated in the highest income brackets, more than the national average. The south is considered the most dynamic region for family farming, with the lowest rate of rural poverty (around $47.4 \%$ of farms) and the lowest PII among all regions studied (0.73). In the centre-west region, the high- and medium-technological-intensity groups display a better distribution of gross income in the highest income brackets. Nonetheless, compared to the other regions analyzed, the low technology intensity group displays a high level of inequality.

Focusing attention on the north-east region, high technological-intensity agriculture generates greater inequality than the region as a whole, which shows that there is a high degree of heterogeneity, even in the most advanced segments. Another finding is that, in the north-east (the most backward region), the higher the level of technological and institutional intensity, the higher the PII. As noted by Vieira Filho, Santos and Fornazier (2012), a pattern of dual convergence can be seen in other regions, which tend to concentrate the most dynamic and modern productions. The high and low technological-intensity groups recorded much lower PIIs than the regional totals, thereby suggesting homogeneous patterns at the extremes of the taxonomy. In the most dynamic region at least, the taxonomy serves to distinguish the more organized economic agents and those with a high level of technology compared to those of more backward production.

It should be noted that the "socialization of poverty" coexists with a "heterogeneity of wealth". In the latter case, in the centre-west region, $0.1 \%$ of the establishments that generate income of more than 200 times the monthly minimum wage produce $23.2 \%$ of GPV. It is curious to note that in the north-east, $0.1 \%$ of establishments in the same income group produced more than $25 \%$ of production. The gross value produced by the high-income bracket in the north-east was 3,400 million reais, while the centre-west region produced 726.4 million reais. In other words, GPV in the north-east was 4.7 times higher than that of the center-west region for the income level in question. This comparison shows how unequal family farming is in the north-east, since this region accounts for much of the country's rural poverty. It can also be seen that, in the high technological-efficiency group in the north-east, $0.2 \%$ of establishments in the high-income bracket (which generated income of more than 200 times the monthly minimum wage) produce roughly $38 \%$ of GPV.

In terms of the "socialization of poverty", especially in the north-east, productive inequality measured by the respective index in low technological-intensity family farming was the lowest in the nation as a whole. Nonetheless, $98.3 \%$ of establishments in this technological

TABLE 5

Brazil: comparison of family farming by technological-intensity group, MWE income bracket and PII, 2006

\begin{tabular}{|c|c|c|c|c|c|c|c|c|c|c|c|c|}
\hline \multirow{2}{*}{ Taxonomy } & & \multirow{2}{*}{$\begin{array}{l}\text { Establishments } \\
\text { (thousand) and } \\
\text { GPV (millions } \\
\text { of reais) }\end{array}$} & \multicolumn{4}{|c|}{ MWE income brackets } & \multirow{2}{*}{ Total } & \multicolumn{4}{|c|}{ Percentages } & \multirow{2}{*}{ PII } \\
\hline & & & (0 to 2$)$ & \multicolumn{2}{|c|}{ (2 to 10$)$ (10 to 200$)$} & \multirow{2}{*}{$\begin{array}{r}>200 \\
0.1\end{array}$} & & \multirow{2}{*}{$\begin{array}{c}\text { (0 to } 2) \\
42.3\end{array}$} & \multicolumn{2}{|c|}{ (2 to 10$)(10$ to 200$)$} & \multirow{3}{*}{$\begin{array}{r}>200 \\
0.2 \\
16.1\end{array}$} & \\
\hline & & No. & 11.2 & 12.2 & 3.1 & & 26.6 & & 45.8 & 11.6 & & \\
\hline TFP $>1$ AT & High & GPV & 50.2 & 202.2 & 343.3 & 114.1 & 709.8 & 7.1 & 28.5 & 48.4 & & 0.1 \\
\hline \multirow{2}{*}{ TFP $>1$ BT } & \multirow{4}{*}{ Medium } & No. & 104.6 & 46.0 & 15.2 & 0.5 & 166.3 & 62.9 & 27.7 & 9.2 & 0.3 & \\
\hline & & GPV & 302.0 & 750.3 & 1736.7 & 788.1 & 3577.2 & 8.4 & 21.0 & 48.6 & 22.0 & 9 \\
\hline \multirow{2}{*}{$\mathrm{TFP}<1 \mathrm{AT}$} & & No. & 28.1 & 2.8 & 0.2 & 0.0 & 31.1 & 90.4 & 9.0 & 0.6 & 0.0 & \multirow{2}{*}{0.40} \\
\hline & & GPV & 71.9 & 38.8 & 16.0 & 0.0 & 126.7 & 56.7 & 30.6 & 12.6 & 0.0 & \\
\hline \multirow{2}{*}{$\mathrm{TFP}<1$ BT } & \multirow{2}{*}{ Low } & No. & 113.7 & 19.4 & 0.9 & 0.0 & 133.9 & 84.9 & 14.5 & 0.7 & 0.0 & \multirow{2}{*}{0.48} \\
\hline & & GPV & 293.6 & 306.3 & 53.5 & 1.8 & 655.3 & 44.8 & 46.8 & 8.2 & 0.3 & \\
\hline
\end{tabular}


Table 5 (concluded)

\begin{tabular}{|c|c|c|c|c|c|c|c|c|c|c|c|c|}
\hline \multirow{2}{*}{ Taxonomy } & & \multirow{2}{*}{$\begin{array}{l}\text { Establishments } \\
\text { (thousand) and } \\
\text { GPV (millions } \\
\text { of reais) }\end{array}$} & \multicolumn{4}{|c|}{ MWE income brackets } & \multirow{2}{*}{ Total } & \multicolumn{4}{|c|}{ Percentages } & \multirow{2}{*}{ PII } \\
\hline & & & (0 to 2$)$ & (2 to 10$)$ ( & (10 to 200 ) & $>200$ & & (0 to 2$)$ & (2 to 10 ) & 0 to 200 ) & $>200$ & \\
\hline \multirow{2}{*}{ North } & & No. & 257.6 & 80.4 & 19.4 & 0.6 & 357.9 & 72.0 & 22.5 & 5.4 & 0.2 & \multirow{2}{*}{0.76} \\
\hline & & GPV & 717.7 & 1297.6 & 2149.5 & 904.0 & 5069.0 & 14.2 & 25.6 & 42.4 & 17.8 & \\
\hline \multirow{2}{*}{$\mathrm{TFP}>1 \mathrm{AT}$} & \multirow{2}{*}{ High } & No. & 207.5 & 69.2 & 19.6 & 0.7 & 297.0 & 69.9 & 23.3 & 6.6 & 0.2 & \multirow{2}{*}{0.82} \\
\hline & & GPV & 628.5 & 1170.2 & 2166.1 & 2445.7 & 6410.5 & 9.8 & 18.3 & 33.8 & 38.2 & \\
\hline \multirow{2}{*}{$\mathrm{TFP}>1 \mathrm{BT}$} & \multirow{4}{*}{ Medium } & No. & 596.2 & 74.5 & 24.4 & 0.4 & 695.4 & 85.7 & 10.7 & 3.5 & 0.1 & \multirow{2}{*}{0.78} \\
\hline & & GPV & 986.4 & 1290.5 & 2449.7 & 936.8 & 5663.3 & 17.4 & 22.8 & 43.3 & 16.5 & \\
\hline \multirow{2}{*}{$\mathrm{TFP}<1$ AT } & & No. & 306.7 & 11.5 & 0.4 & 0.0 & 318.6 & 96.3 & 3.6 & 0.1 & 0.0 & \multirow{2}{*}{0.29} \\
\hline & & GPV & 453.4 & 159.6 & 35.3 & 0.0 & 648.4 & 69.9 & 24.6 & 5.4 & 0.0 & \\
\hline & & No. & 657.5 & 11.1 & 0.4 & 0.0 & 669.0 & 98.3 & 1.7 & 0.1 & 0.0 & \\
\hline $\mathrm{TFP}<1 \mathrm{BT}$ & Low & GPV & 490.9 & 163.7 & 23.8 & 0.9 & 679.2 & 72.3 & 24.1 & 3.5 & 0.1 & 0.21 \\
\hline & & No. & 1767.9 & 166.3 & 44.8 & 1.1 & 1980.0 & 89.3 & 8.4 & 2.3 & 0.1 & \\
\hline Norm-east & & GPV & 2559.2 & 2784.0 & 4674.9 & 3383.4 & 13401.4 & 19.1 & 20.8 & 34.9 & 25.2 & 0.18 \\
\hline TFP $>1$ AT & High & GPV & 189.2 & 1548.9 & 3811.3 & 2319.1 & 7868.5 & 2.4 & 19.7 & 48.4 & 29.5 & 0.12 \\
\hline TFP & & No. & 42.0 & 20.2 & 7.5 & 0.1 & 69.9 & 60.1 & 28.9 & 10.8 & 0.2 & 079 \\
\hline $1 \mathrm{FP}$ & & GPV & 113.8 & 378.1 & 771.1 & 366.3 & 1629.1 & 7.0 & 23.2 & 47.3 & 22.5 & 0.19 \\
\hline & vedium & No. & 164.2 & 47.4 & 6.4 & 0.0 & 218.0 & 75.3 & 21.7 & 2.9 & 0.0 & \\
\hline TFP & & GPV & 428.6 & 803.1 & 479.8 & 8.4 & 1720.0 & 24.9 & 46.7 & 27.9 & 0.5 & 0.63 \\
\hline & J ow & No. & 137.4 & 17.3 & 1.2 & 0.0 & 155.9 & 88.2 & 11.1 & 0.7 & 0.0 & 060 \\
\hline $1 \mathrm{FP}<1 \mathrm{~B}$ & Low & GPV & 184.7 & 296.3 & 70.8 & 0.0 & 551.7 & 33.5 & 53.7 & 12.8 & 0.0 & 0.00 \\
\hline & & No. & 386.4 & 163.0 & 49.5 & 0.8 & 599.8 & 64.4 & 27.2 & 8.3 & 0.1 & \\
\hline south-east & & GPV & 916.3 & 3026.4 & 5133.0 & 2693.8 & 11769.3 & 7.8 & 25.7 & 43.6 & 22.9 & .19 \\
\hline $\mathrm{TFP}>1$ & High & No. & 58.5 & 196.0 & 79.1 & 1.0 & 334.6 & 17.5 & 58.6 & 23.6 & 0.3 & 064 \\
\hline $1 \mathrm{FP}>1 \mathrm{AI}$ & Пign & GPV & 289.2 & 4091.5 & 9093.0 & 2866.5 & 16340.2 & 1.8 & 25.0 & 55.6 & 17.5 & 0.04 \\
\hline & & No. & 23.4 & 9.3 & 3.3 & 0.1 & 36.0 & 64.9 & 25.8 & 9.1 & 0.2 & 079 \\
\hline TFP $>1 \mathrm{BT}$ & & GPV & 67.8 & 174.1 & 374.1 & 168.4 & 784.4 & 8.6 & 22.2 & 47.7 & 21.5 & .19 \\
\hline & Medium & No. & 211.5 & 105.1 & 16.1 & 0.0 & 332.8 & 63.6 & 31.6 & 4.8 & 0.0 & \\
\hline TFP $<1$ AT & & GPV & 660.2 & 1879.5 & 1185.5 & 15.9 & 3741.0 & 17.6 & 50.2 & 31.7 & 0.4 & 0.03 \\
\hline TFP $<1$ BT & J 0 w & No. & 82.3 & 6.7 & 0.3 & 0.0 & 89.2 & 92.2 & 7.5 & 0.3 & 0.0 & 50 \\
\hline soum & & GPV & 1126.8 & 6249.9 & 10675.0 & 3050.8 & 21102.5 & 5.3 & 29.6 & 50.6 & 14.5 & 0.73 \\
\hline & High & No. & 5.4 & 12.3 & 4.7 & 0.1 & 22.6 & 23.8 & 54.7 & 20.9 & 0.5 & 074 \\
\hline TFP & Hign & GPV & 28.3 & 227.2 & 607.8 & 442.5 & 1305.8 & 2.2 & 17.4 & 46.5 & 33.9 & .14 \\
\hline & & No. & 9.1 & 11.6 & 4.1 & 0.0 & 24.9 & 36.6 & 46.8 & 16.4 & 0.2 & \\
\hline $1 \mathrm{FP}>1 \mathrm{BI}$ & Medium & GPV & 34.7 & 233.8 & 383.5 & 265.9 & 917.9 & 3.8 & 25.5 & 41.8 & 29.0 & .13 \\
\hline & viedim & No. & 37.7 & 9.5 & 1.5 & 0.0 & 48.7 & 77.5 & 19.5 & 3.1 & 0.0 & 065 \\
\hline $1 \mathrm{FP}<1$ AI & & GPV & 109.5 & 150.2 & 139.5 & 17.9 & 417.2 & 26.3 & 36.0 & 33.4 & 4.3 & 0.05 \\
\hline TFP $<$ & & No. & 60.3 & 17.2 & 1.1 & 0.0 & 78.7 & 76.7 & 21.9 & 1.4 & 0.0 & \\
\hline TFP $<1$ & Low & GPV & 132.0 & 292.6 & 68.9 & 0.0 & 493.4 & 26.7 & 59.3 & 14.0 & 0.0 & .59 \\
\hline Centre-west & & No. & 112.5 & 50.7 & 11.4 & 0.2 & 174.8 & 64.4 & 29.0 & 6.5 & 0.1 & 077 \\
\hline Centre-west & & GPV & 304.5 & 903.8 & 1199.7 & 726.4 & 3134.4 & 9.7 & 28.8 & 38.3 & 23.2 & 0.17 \\
\hline & High & No. & 325.5 & 367.9 & 140.9 & 2.5 & 836.7 & 38.9 & 44.0 & 16.8 & 0.3 & 74 \\
\hline TFP > I AT & Hign & GPV & 1185.4 & 7239.9 & 16021.5 & 8187.9 & 32634.8 & 3.6 & 22.2 & 49.1 & 25.1 & 0.14 \\
\hline & & No. & 775.2 & 161.7 & 54.5 & 1.1 & 992.5 & 78.1 & 16.3 & 5.5 & 0.1 & 1 \\
\hline $1 \mathrm{BT}$ & Medium & GPV & 1504.7 & 2826.7 & 5715.1 & 2525.5 & 12571.9 & 12.0 & 22.5 & 45.5 & 20.1 & 1 \\
\hline & Drearum & No. & 748.3 & 176.2 & 24.7 & 0.0 & 949.2 & 78.8 & 18.6 & 2.6 & 0.0 & 4 \\
\hline $1 \mathrm{FP}<1$ AT & & GPV & 1723.6 & 3031.3 & 1856.1 & 42.2 & 6653.2 & 25.9 & 45.6 & 27.9 & 0.6 & .04 \\
\hline $\mathrm{TFP}<1 \mathrm{BT}$ & Low & No. & 1051.1 & 71.7 & 3.8 & 0.0 & 1126.6 & 93.3 & 6.4 & 0.3 & 0.0 & 051 \\
\hline $1 \mathrm{FP}<1 \mathrm{BI}$ & Luw & GPV & 1210.7 & 1163.7 & 239.4 & 2.7 & 2616.5 & 46.3 & 44.5 & 9.1 & 0.1 & 0.J1 \\
\hline & & No. & 2900.1 & 777.5 & 223.9 & 3.6 & 3905.1 & 74.3 & 19.9 & 5.7 & 0.1 & \\
\hline Brazil & & GPV & 5624.4 & 14261.6 & 23832.11 & 10758.3 & 54476.4 & 10.3 & 26.2 & 43.7 & 19.7 & .80 \\
\hline
\end{tabular}

Source: prepared by the author on the basis of Brazilian Geographical and Statistical Institute (IBGE). 2006 Census of Agriculture.

TFP: total factor productivity.

HT: high technological/institutional content.

LT: low technological/institutional content.

GPV: gross production value.

PII: productive inequality index.

MWE: minimum wage equivalent. 
group generate income in the range of zero to two times the monthly minimum wage, so many of them are extremely poor. The percentage of establishments compared to GPV shows that in the more modern regions there is a larger number of producers in the higher income strata. In general, however, establishments in the most backward regions are mostly concentrated in the lower income strata. The PII of the average technological-intensity group displays greater inequality, which shows that the diversity of such establishments is much more complex.

The analytical methodology was used to compare the PII with labour productivity, measured in both cases using standardized indicators. In this comparison, as shown in figure 5 , the labour productivity data for commercial agriculture are more dispersed, whereas the corresponding figures for family farming are more concentrated and more static. The quadrant that identifies low productive inequality combined with high productivity ("homogenization of wealth") contains three observations, two of them commercial farming and one family farming.

The quadrant representing high inequality combined with low productivity predominantly consists of commercial farming. In that group, which requires specific policies to raise productivity, inequality levels are high, because production is more dynamic and can be affected by seasonal fluctuations and other shocks external to the market. With regard to the "heterogeneity of wealth" (represented by the upper right-hand quadrant), commercial and family farms alternate, and the latter are concentrated more in the interior figure 5. The lower left-hand quadrant (typical of the "socialization of poverty") is essentially populated by family farming. As noted above, there are many establishments with low productivity and low levels of inequality, because they share a very similar low production characteristic.

An analysis of figure 6, which focuses on family farming alone, shows that high and medium technologicalintensity farms are concentrated on the right-hand side of figure 6 , which represents higher labour productivity. The left-hand portion distinguishes low and medium technology-intensity establishments. The results show that structural heterogeneity is present in all regions, but in varying degrees in each case (as shown by the size of the standard deviation of labour productivity and the PII). Although the data reflect what would normally be expected in the typical pattern of Brazilian agriculture, they qualify analyses of the productive and technological concentration process. In the lowinequality/high-productivity quadrant ("homogenization of wealth"), the south region includes establishments

FIGURE 5

Brazil: PII compared to labour a productivity by type of farming (commercial or family), 2006

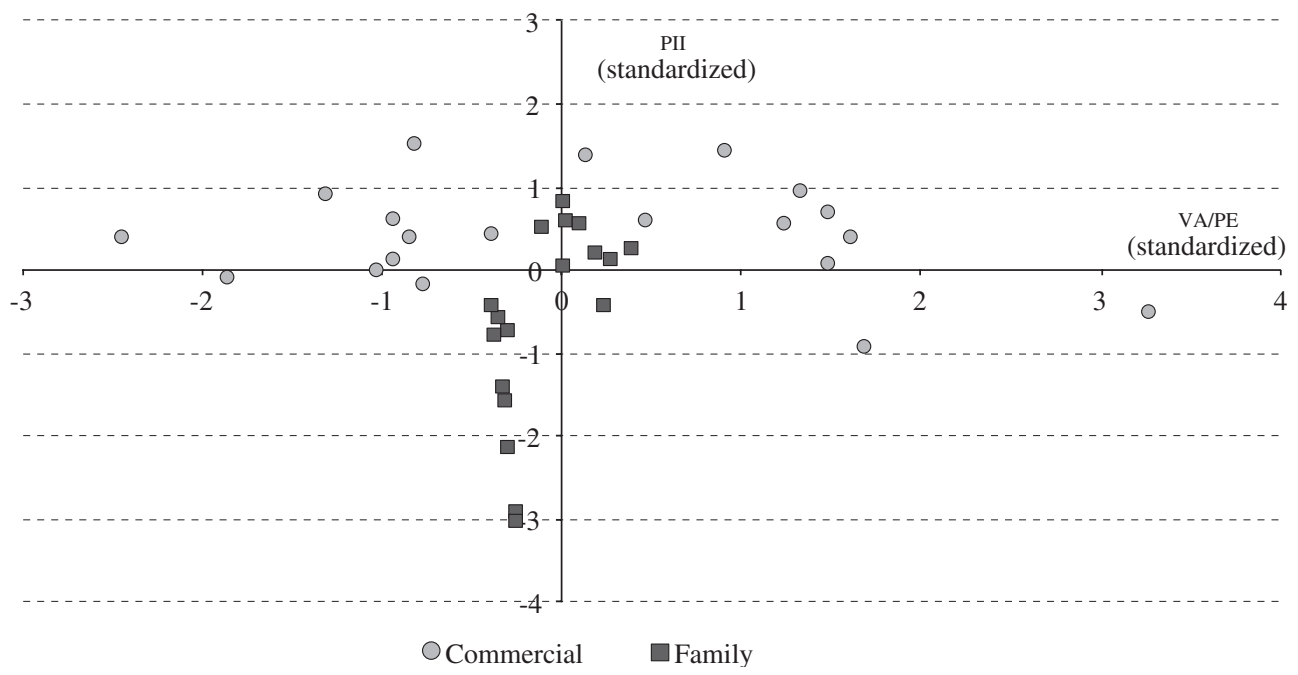

Source: prepared by the author on the basis of Brazilian Geographical and Statistical Institute (IBGE), 2006 Census of Agriculture.

a Standardized indicators.

PII: productive inequality index.

VA/PE: value added per population employed. 
of high technological intensity, which makes clear that family farming can combine high technology, high labour productivity, and low productive inequality, provided there is an institutional environment that encourages growth and technological innovations.

The medium technological-intensity group needs to be studied in greater depth in this context, because it shows dispersion both in productive inequality and in labour productivity, without displaying a well-defined pattern. The category of low productive inequality combined with low productivity ("socialization of poverty") is clearly dominated by family farming, and the situation is particularly critical in the north east and north regions. As a stylized facts of the analysis of figure 6, it can be FIGURE 6
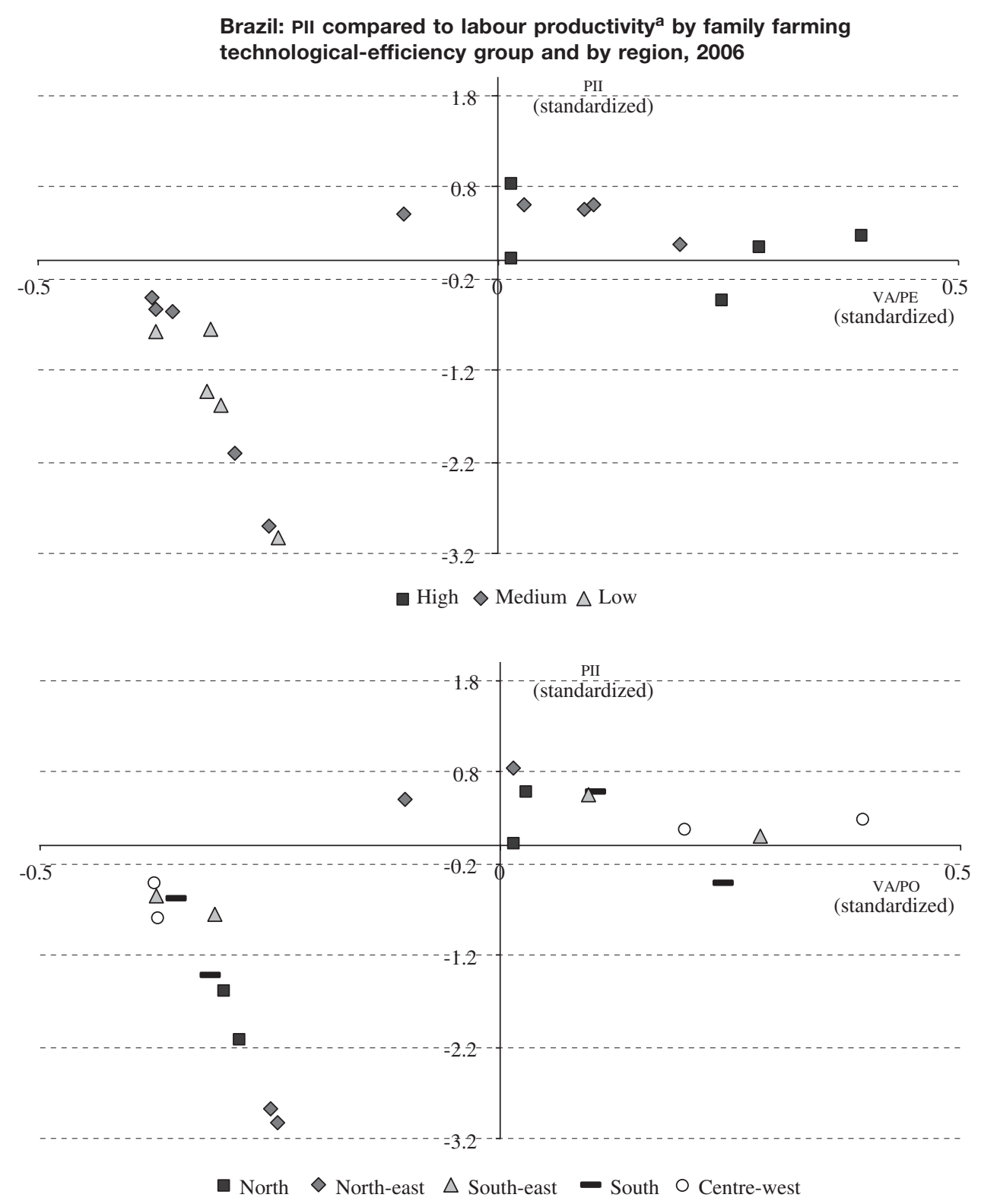

Source: prepared by the author on the basis of Brazilian Geographical and Statistical Institute (IBGE), 2006 Census of Agriculture.

${ }^{a}$ Standardized indicators.

PII: productive inequality index.

$\mathrm{VA} / \mathrm{PE}$ : value added per population employed. 
seen that the most dynamic regions for family farming are shown more to the right of that figure (centre-west, south and south-east), whereas the more static regions are shown more to the left and normally low down in figure

\section{IV}

\section{Final thoughts}

In recent decades, the Brazilian agricultural sector has undergone many changes, prompting an intensive modernization process, greater technological progress and high productivity. Nonetheless, there are still producers who combine low technological content with low productivity. Agriculture cannot simply be divided into modern and backward producers. There are structural problems that create inefficiency in the management of technological resources and the use of productive factors, resulting in an environment that is unconducive to innovations in products and processes or the dissemination of new knowledge.

This paper has sought to identify and quantify the structural heterogeneity in family farming, which prevents backward segments from participating in dynamic markets. First, from the standpoint of public policymaking, the study shows that the distinction between family and commercial farming can be ignored, because the results reveal the coexistence of modern productive agents and backward ones within the same group. The internal diversity of family farming therefore requires specific actions to promote production and reallocate resources to the different segments. Secondly, regional specifics loom very large, so regional planning and development need to be targeted.

The comparison between Brazil's different regions and between technology groups found significant productive and technological heterogeneity in family farming, which seems to verify the initial hypothesis that technological innovations driven by institutional changes serve to increase the heterogeneity of the system and benefit the most innovative participants.

The empirical evidence shows that about $5 \%$ of the wealthiest family farms accounted for $64 \%$ of GPV, while the poorest $66 \%$ generated roughly $10 \%$ of total output. Furthermore, family farms account for an estimated $90 \%$ of the lowest income group, defined as from zero to two times the minimum wage. There is thus a strong pattern of gross income concentration, on the one hand, and a heavy burden of extreme poverty in family farming, on
6, which indicates patterns reflecting the homogeneity of poverty (north and north-east regions). The standard deviation rises or falls according to regional production and development patterns. the other. In analyzing the economic viability of the 4.4 million family farms in 2006, $42 \%$ had a gross income that exceeded total costs, or a positive net income. At the other end of the spectrum, however, more than half of the establishments were in an unfavourable financial situation.

In terms of labour productivity, it was possible to compare the agriculture sector with other sectors of economic activity in Brazil. While global data suggest that Brazilian agriculture is less productive than other sectors (industry and services), technological stratification reveals a high level of heterogeneity in labour productivity between productive establishments. The most productive agriculture has labour productivity that is almost seven times the national average for the sector; but family farms have low levels of labour productivity with less variability.

A comparison of labour productivity with the PII, reveals two patterns: (i) "heterogeneity of wealth"; and (ii) "socialization of poverty." In establishments of higher technological content, according to the taxonomy, the higher indicators of inequality and labour productivity obtained varied somewhat between the regions studied. In the most backward regions (specifically in the northeast), family farming is more unequal and accounts for a large proportion of rural poverty, although dual development can be observed (coexistence of modern and backward sectors in the same economic space). In the south there was a more homogeneous pattern of production, and income levels are above average. The south is also considered the most dynamic region for family farming, with the lowest rural poverty rate (47\% of productive establishments in the regional total) and the lowest inequality index (0.73) among all regions studied.

In the group combining medium technological intensity and TFP less than 1, policies (including short-term ones) are needed to reverse the situation of negative net income, to increase productive efficiency. This result may be partly blamed on seasonal fluctuations, but another part clearly stems from technological inefficiency; and the low technological-intensity group contains numerous 
unproductive establishments. Firstly, structural policies are needed to increase capacity for technology absorption, rural extension and education; and secondly, short-term measures are needed, such as policies for disadvantaged groups and income transfer.

In the high technological-intensity group, although net income is positive, partly because of spending on land-saving and labour saving technologies, TFP did not attain its highest value. Except in the case of seasonal problems, this group of establishments can use its resources more efficiently to increase capacity to absorb external knowledge, which can be stimulated by management training policies specific to the crop and the region in question. Usually targeted on the high technological-efficiency group, horizontal policies to improve competitiveness help reduce production costs, which can at the same time help in terms of increasing and appropriating income.
A more comprehensive study that includes cropspecific analyses will help define public policies, taking regional and productive specifics into account. Nonetheless, the country also needs a clear policy for increasing technology absorption capacity, which entails making progress in rural extension and education. This requires policies that are more closely integrated across the federal, state and municipal levels, to reach the grassroots of the system, spreading the new techniques and knowledge in a way that reaches the producer. Transforming market-based family farming will be the main challenge for agricultural planning and policy in Brazil over the next few years. It should also be noted that the proposed methodology provides a basis for comparison, for example with other Latin American countries, since the region as a whole has characteristics and challenges that are relatively similar to those of Brazil.
Alves, E. and D. Rocha (2010), "Ganhar tempo é possivel", A agricultura brasileira: desempenho, desafios e perspectivas, J.G. Gasques, J.E.R. Vieira Filho and Z. Navarro (orgs.), Institute of Applied Economic Research (IPEA).

Alves, E., G.S. Souza and C.A.V. Oliveira (2006), "Desempenho de establecimentos do Pronaf", Migração rural-urbana, agricultura familiar e novas tecnologias: coletânea de artigos revistos, E. Alves (ed.), Brasilia, Embrapa Informação Tecnológica.

Brasil (2006), "Lei $\mathrm{N}^{\circ} 11.326 ", 24$ July.

Buainain, A.M. (ed.) (2007), Agricultura familiar e inovação tecnológica no Brasil: características, desafios e obstáculos, Campinas, State University at Campinas.

Cohen, W.M. and D.A. Levinthal (1989), "Innovation and learning: the two faces of R\&D", The Economic Journal, vol. 99, No. 397, Wiley.

ECLAC (Economic Commission for Latin America and the Caribbean) (2010), Time for equality: closing gaps, opening trails (LC/G.2432(SES.33/3)), Santiago, Chile.

Evenson, R.E. and Y. Kislev (1973), "Research and productivity in wheat and maize", Journal of Political Economy, vol. 81, No. 6, Chicago, The University of Chicago Press.

Fornazier, A. and J.E.R. Vieira Filho (2012), "Heterogeneidade estrutural no setor agropecuário brasileiro: evidências a partir do censo agropecuário de 2006", Texto para discusión, No. 1708, Rio de Janeiro, Institute of Applied Economic Research (IPEA).

Gasques, J.G. and others (2010), "Produtividade total dos fatores e transformações da agricultura brasileira: analise dos dados dos censos agropecuários", A agricultura brasileira: desempenho, desafios e perspectivas, J.G. Gasques, J.E.R. Vieira Filho and Z. Navarro (orgs.), Institute of Applied Economic Research.

Hoffmann, R. (2011), "Distribuição da renda agrícola e sua contribuição para a desigualdade de renda no Brasil", Revista de Política Agrícola, year XX, No. 2, Brasilia, Secretariat of Agricultural Policy.

(1998), Distribuição de renda: medidas de desigualdade e pobreza, São Paulo, Editora da Universidade de São Paulo.

IPEA (Institute of Applied Economic Research) (2011), Radar: Tecnologia, Produção e Comercio Exterior, No. 14, Brasilia.
Matteo, M. (2011), "Heterogeneidade regional", Radar: Tecnologia, Produção e Comercio Exterior, No. 14, Brasilia, Institute of Applied Economic Research (IPEA).

Navarro, Z. and M.T.M. Pedroso (2011), "Agricultura familiar: é preciso mudar para avançar", Texto para discusión, No. 42, Brazilian Agricultural Research Corporation (Embrapa).

Nohlen, D. and R. Sturm (1982), "La heterogeneidad estructural como concepto básico en la teoría de desarrollo", Revista de Estudios Políticos, No. 28, Madrid, Centro de Estudios Políticos y Constitucionales.

Pinto, A. (1970), "Naturaleza e implicaciones de la heterogeneidad estructural", El trimestre económico, vol. 37, No. 1, Mexico City, Fondo de Cultura Económica.

Sunkel, O. and R. Infante (eds.) (2009), Hacia un desarrollo inclusivo: El caso de Chile (LC/L.3126), Santiago, Chile, Economic Commission for Latin America and the Caribbean (ECLAC).

Vieira Filho, J.E.R. (2010), “Trajetória tecnológica e aprendizado no setor agropecuário", A agricultura brasileira: desempenho, desafios e perspectivas, J.G. Gasques, J.E.R. Vieira Filho and Z. Navarro (orgs.), Institute of Applied Economic Research (IPEA). (2009), "Inovação tecnológica e aprendizado agrícola: uma abordagem Schumpeteriana", Ph.D. thesis, Campinas, State University at Campinas.

Vieira Filho, J.E.R., A.C. Campos and C.M.C. Ferreira (2005), "Abordagem alternativa do crescimento agrícola: um modelo de dinâmica evolucionária”, Revista Brasileira de Inovação, vol. 4, No. 2, Campinas, State University at Campinas.

Vieira Filho, J.E.R. and G.R. Santos (2011), "Heterogeneidade no setor agropecuário brasileiro: contraste tecnológico", Radar: Tecnologia, Produção e Comercio Exterior, No. 14, Brasilia, Institute of Applied Economic Research (IPEA).

Vieira Filho, J.E.R., G.R. Santos and A. Fornazier (2012), "Distribuição produtiva e tecnológica da agricultura brasileira e sua heterogeneidade estrutural", Brasilia, Institute of Applied Economic Research (IPEA).

Vieira Filho, J.E.R. and J.M.F. Silveira (2011), "Modelo evolucionário de aprendizado agrícola", Revista Brasileira de Inovação, vol. 10, No. 2, Campinas, State University at Campinas. 